Too Much Trust: Regional Party Leaders and Local Political Networks under Brezhnev Author(s): Yoram Gorlizki

Source: Slavic Review, Vol. 69, No. 3 (FALL 2010), pp. 676-700

Published by:

Stable URL: http://www.jstor.org/stable/25746277

Accessed: $17 / 06 / 2014$ 05:00

Your use of the JSTOR archive indicates your acceptance of the Terms \& Conditions of Use, available at http://www.jstor.org/page/info/about/policies/terms.jsp

JSTOR is a not-for-profit service that helps scholars, researchers, and students discover, use, and build upon a wide range of content in a trusted digital archive. We use information technology and tools to increase productivity and facilitate new forms of scholarship. For more information about JSTOR, please contact support@ jstor.org. 


\section{Too Much Trust: Regional Party Leaders and Local Political Networks under Brezhnev}

\section{Yoram Gorlizki}

Early in his tenure, at the Twenty-third Party Congress in March 1966, Leonid Brezhnev coined a new slogan, "trust in cadres [doverie k kadram]." Widely repeated at the congress and in its immediate aftermath, this phrase would become one of the lasting refrains of the Brezhnev era. The Soviet leadership's fondness for the expression did not go unnoticed abroad. "We have now read for eleven years of the need for "trust in cadres," "wrote one foreign observer, with a certain weariness, in $1977 .{ }^{2}$ Five years later, as the Brezhnev administration came to an end, the same author concluded that "the notion of 'trusting the cadres' [has become] a virtual byword of the Brezhnev regime."

Although the campaign for "trust in cadres" received ample attention from contemporaries, it was often viewed from a relatively narrow institutional perspective. One measure of this was its conflation with the closely connected but nonidentical phrase "stability of cadres." "Stability of cadres" was normally taken to refer to Brezhnev's policy of reducing the turnover of senior officials. ${ }^{5}$ At a time when reliable information on the Soviet system was scarce, commentators were drawn to this policy for the simple reason that it turned on a metric-rates of cadre turnover-that was easily measurable and relatively accessible from published sources. ${ }^{6}$ By

Work for this article was supported by a major grant from the U.K. Economic and Social Research Council, "Networks and Hierarchies in the Soviet Provinces, 1945-1970" (RES000-23-0880), and by subsidiary grants from the British Academy (SG-42559, SG-48370). Draft papers and archival materials from the larger project on which this article draws can be found at www.socialsciences.manchester.ac.uk/sovietprovinces. I am very grateful to the Russian codirector of the project, Oleg Khlevniuk, for supplying the archival documents consulted and for his many ideas. Earlier versions were presented at a workshop in Manchester in September 2006, at the annual convention of the American Association for the Advancement of Slavic Studies in New Orleans in November 2006, and at the CEELBAS Midlands Russia Seminar at the Institute for Advanced Study, University of Warwick, in December 2009. Special thanks go to Mark Harrison for his stimulating readings of various drafts of the paper. I am also grateful to the commentator in New Orleans, Brian LaPierre, and to Mark D. Steinberg, for their thoughtful criticisms and comments.

1. XXIII S"ezd Kommunisticheskoi partii Sovetskogo Soiuza, 29 marta-8 aprelia 1966 goda. Stenograficheskii otchet (Moscow, 1966), 1:89.

2. George W. Breslauer, "The Twenty-fifth Congress: Domestic Issues," in Alexander Dallin, ed., The Twenty-fifth Congress of the CPSU: Assessment and Context (Stanford, 1977), 8.

3. George W. Breslauer, Khrushchev and Brezhnev as Leaders: Building Authority in Soviet Politics (London, 1982), 154.

4. See, for example, William A. Clark, Soviet Regional Elite Mobility after Khrushchev (New York, 1989), 114-23.

5. See, for example, T. H. Rigby, "The Soviet Leadership: Towards a Self-Stabilizing Oligarchy?" Soviet Studies 22, no. 2 (October 1970): 179; and Robert E. Blackwell Jr., "Cadre Policy in the Brezhnev Era," Problems of Communism 28, no. 2 (March-April 1979): 31-33.

6. Blackwell, "Cadre Policy in the Brezhnev Era," 31-37.

Slavic Review 69, no. 3 (Fall 2010) 
contrast, the wider campaign for "trust in cadres" revolved around more nuanced themes, such as the changing nature of political relationships and the development of collective political norms, analysis of which went beyond the scope of contemporary sources. Newly available materials now allow us to reconstruct aspects of these relationships that eluded an earlier generation of scholars. Probing more deeply into the "trust in cadres" campaign affords us a glimpse of the informal aspects of Brezhnev-era politics that an examination of the lists of promotions, dismissals, and retirements alone would not pick up.

I propose that the widespread application of the term trust (doverie) in official discourse under Brezhnev was not a matter of chance and that our understanding of its use can benefit from how the notion of trust has been elaborated by social scientists and historians in other contexts. While full coverage of the enormous literature on trust is beyond the scope of this paper, one commonly held distinction from this body of work is of direct relevance to our theme. Most commentators distinguish between "trust in institutions" and "trust in persons" where the former refers to individuals' attitudes and orientations toward public agencies (for example, in the form "trust in parties" or "trust in government") and the latter to forms of trust that emerge from directly experienced interpersonal relationships. ${ }^{7}$ To some scholars, the gulf between these conceptions of trust is so great that they dismiss the notion of "trust" in institutions altogether-preferring an alternative term, such as confidence-given that most ordinary people do not have the depth or quality of information to judge large institutions in the way that they can close individuals with whom they interact on a regular basis. ${ }^{8}$ At first glance, the campaign for "trust in cadres" appears to be little more than an example of "trust in institutions," a composite of state-endorsed attitudes on the standing of public agencies and their officeholders. I shall argue, however, that there was a strong connection between the emphasis political leaders placed on "trust in cadres" and the development of interpersonal relations among officials and that it is partly for this reason that the slogan became so popular. Moreover, local leaders were in effect encouraged by the Brezhnev leadership to forge relations of "trust," by which I mean ties grounded in ongoing personal relationships that could lead to cooperation on certain matters. ${ }^{9}$ Although the reasons

7. For a secondary distinction between strategic trust (i.e., trust in people we know well) and generalized or social trust (i.e., faith in strangers) that discounts the latter as an example not of "trust" but of "faith," see Russell Hardin, Trust and Trustworthiness (New York, 2002), 56, 60-62.

8. Such scholars prefer alternative terms, such as confidence or quasi-trust to describe the relationship individuals have to institutions. See Niklas Luhmann, "Familiarity, Confidence, Trust," in Diego Gambetta, ed., Trust: Making and Breaking Cooperative Relations (Oxford, 1988), 98-99, 102-3; and Hardin, Trust and Trustworthiness, 151-52, 158-59.

9. Although definitions of trust are notoriously slippery, standard conceptions ground trust in an ongoing personal relationship where the trusted has the freedom to act against the interests of the truster but where the relationship provides, nevertheless, a basis for cooperation on certain matters. This basic understanding is shared by conceptions as varied as Tilly's "transactional," Hardin's "cognitive," and Luhmann's "systemic" accounts of trust. See Charles Tilly, Trust and Rule (New York, 2005), 4, 12, 24, 45; Hardin, 
for this are complex, the Soviet leadership turned to trust as a "lubricant" that allowed its cumbersome political and economic institutions, marked by high transaction costs, to function more smoothly. ${ }^{10}$ We may thus view the new emphasis on "trust" of the early Brezhnev period as signalling a rolling back of the crude "administrative measures" of the Khrushchev era, which had relied on the manipulation of organizational incentives, in favor of a set of informal arrangements organized around personal relationships that could compensate for the flawed formal institutions of the Soviet system.

I shall focus on the leadership of the territorial party apparatus, a group whose members were, according to George Breslauer, the "principal beneficiaries of the policy of "trusting the cadres." "11 My central focus will be the hub of the regional party organization, the regional first secretary, and the networks that formed around him. ${ }^{12}$ An examination of the speeches of the period shows that the leaders of the territorial party apparatus were among the most enthusiastic proponents of the slogan. ${ }^{13}$ One reason for this may have been that it was collectively this group that had suffered most at the hands of Nikita Khrushchev's administrative reorganizations of the early 1960s and whose autonomy had been most curtailed by them. ${ }^{14}$ By contrast, under the new post-Khrushchev order, regional first secretaries were granted considerable latitude to run their own affairs, often on the basis of personal "understandings" with the leader. "The first secretaries were given almost unlimited power in their regions," recalled Mikhail Gorbachev, himself a regional first secretary under Brezhnev, "and they, for their part, had to support the general [secretary] . . . this was the essence of the 'gentleman's agreement." 15 As I see it, the slogan

Trust and Trustworthiness, 3, 4-5, 14; Luhmann, "Familiarity," 97, 99. Two areas of contention in the trust literature center on the types of motivation of the trusted and the extent to which trust is behavioral (e.g., Tilly) or cognitive (e.g., Hardin). According to the latter, influential view, trust (an assessment by the truster about the intentions of the trusted) must be distinguished from trustworthiness (the motivations and competence of the trusted). From this perspective, "trust," which is cognitive, must be differentiated from "acting on trust" (for example, through actual cooperation), which is behavioral. See Hardin, Trust and Trustworthiness, chaps. 1, 2.

10. For a discussion of trust as an "extremely effective lubricant" in an institutional environment marked by high transaction costs, see Edward H. Lorenz, "Neither Friends nor Strangers: Informal Networks of Subcontracting in French Industry," in Gambetta, ed., Trust, 198.

11. Breslauer, "Twenty-fifth Congress," 17.

12. In what follows, by regional first secretaries I refer to the leaders of obkoms and kraikoms that, in the RSFSR, were directly subordinate to the Central Committee and, in other republics, were one tier below the republic-level party organization. The male pronoun is used here advisedly. All regional first secretaries in the period covered by this article were men.

13. See, for example, Plenum tsentral' nogo komiteta kommunisticheskoi partii sovetskogo soiuza, 24-26 marta 1965 goda (Moscow, 1965), 219; XXIII S"ezd, 1:522, 2:128; A. B. Konovalov, Partiinaia nomenklatura Sibiri v sisteme regional'noi vlasti (1945-1991) (Kemerovo, 2006), 47.

14. See Nikita Khrushchev 1964: Stenogrammy plenuma TsK KPSS $i$ drugie dokumenty (Moscow, 2007), 245-46, 247, 373-74, 378, 379, 392; and General' nyi sekretar' L. I. Brezhnev 1964-1982 (Moscow, 2006), 16.

15. Mikhail Gorbachev, Zhizn' i reformy (Moscow, 1995), 1:180. 
"trust in cadres" was so widely used, especially by regional leaders, because it was seen as code for these personal arrangements.

It would be wrong to imply that Brezhnev abandoned institutional constraints on regional party leaderships altogether. In many respects it was quite the reverse. The early Brezhnev period witnessed a return to orthodox Leninist controls. In the first half of 1965 the Brezhnev leadership carried out a discreet mini-purge of regional leaders, and in the second half of that year Brezhnev disbanded the network of party-state control agencies in favor of the traditional territorial organizations. At the regional level a set of fine-grained institutional controls were also introduced. These were accompanied by a new set of regional-level norms that were, in many respects, the oligarchic norms of collective leadership that Brezhnev and his associates had espoused in Moscow, except that now they were writ large and extended to the provincial level. ${ }^{16}$ Yet so long as regional leaders abided by these controls and complied with these norms, they were given greater room for "creativity" and "initiative." For many regional cadres, including the regional leaders themselves, this was construed as effective permission to shift the balance of governance away from administrative controls and toward informal mechanisms that were based on ongoing personal relationships.

\section{“Trust in Cadres" and Regional Political Networks under Brezhnev}

Keeping track of networks of interpersonal relations in a state with over 140 regions poses a major challenge. In the space of an article it is not feasible to cover all of these networks in their full variety. Instead, I build on three regional "ideal-types" postulated by the Russian historian Oleg Khlevniuk in two recent papers on regional networks in the 1950s and the early 1960s. ${ }^{17}$ Khlevniuk's analysis is not based on a full statistical sample of all regions, nor does he suggest that all regions conformed exactly to his ideal types. His categories do, however, provide a guide to the kinds of interactions that existed between leaders and the networks around them. From an exhaustive analysis of more than thirty regions, he suggests that although important variations existed, most provinces did tend to gravitate toward one or another of his models.

The first of Khlevniuk's ideal-types had at its epicenter a strong-willed first secretary, a so-called Secretary Dictator. In such regions, formal political institutions were neglected, and matters of consequence were referred directly to the leader. Secretary Dictators tended to flout collective

16. On the new norms of collective leadership in Moscow, see Rigby, "Soviet Leadership," 173-83; Grey Hodnett, "The Pattern of Collective Leadership," in Seweryn Bialer, ed., The Domestic Context of Soviet Foreign Policy (Boulder, Colo., 1981), 95-96; and Dennis Ross, "Coalition Maintenance in the Soviet Union," World Politics 32, no. 2 (January 1980): 264.

17. Oleg Khlevniuk, "Regional'naia vlast' v SSSR v 1953-kontse 1950-kh godov: Ustoichivost' i konflikty," Otechestvennaia istoriia, no. 3 (July 2007): 31-49; and Khlevniuk, "Razdelenie apparata-razdelenie setei" (unpublished paper on the effects on regional networks of the 1962 division of the regional party apparatus, 2007). The latter is cited with permission. 
political norms by intentionally promoting their own associates, many of whom had tainted pasts, over the heads of their peers and immediate superiors. As well as stirring up resentment among the rank and file, this tactic made the promoted individuals beholden to the first secretary and turned them - whether they liked it or not-into his "clients." Often perceived as "rude" and "brusque," Secretary Dictators tended to cultivate a small group of such "clients" over and above ordinary "colleagues." The core political networks in such regions tended to be narrowly constituted and closely tied to the leader. ${ }^{18}$

The second type of region was marked by "Weak Secretaries." Weak Secretaries were often themselves former regional "clients" who had been propelled to positions of prominence by their now departed predecessor. As beneficiaries of overpromotion, they were often the target of resentment and hostility within the region and were rarely in a position to elevate their own people to positions of influence. Instead, they had to contend with formidable rival networks within their own regions. Despite the considerable discretion they enjoyed, leaders of these alternative networks could become wary of a decline in discipline and dissatisfied with the first secretary's poor contacts and prestige in Moscow and could try to remove him, even if this came at a cost to their own autonomy. ${ }^{19}$

The third ideal-type identified by Khlevniuk had "norm-bound networks" (kompromissnye seti). Here the first secretary and the regional networks adhered to the unwritten code or "hierarchical ethics" of the regional elite. Unwritten norms might include promotion by seniority, the elevation of local officials rather than outsiders, and the maintenance of standards of politeness and decorum in everyday intercourse. Although the first secretary was not a dictator, he was normally regarded as a "strong leader" who would impose his stamp on local affairs. Political networks in these regions could be quite extensive, but they were generally held together by a relatively strong first secretary and by the system of hierarchical ethics that prioritized order and a relatively stable system of status differentiation.

I shall argue that, although at the beginning of the Brezhnev period, some regions still gravitated toward one or other of the first two models, by the end of the 1960s they began increasingly to be squeezed into the third model. It was in these regions that the leadership arrangements that were forming at the time in Moscow around Brezhnev were most clearly replicated. At the same time, it was also in these regions that the discourse of "trust in cadres" was most pronounced. Although first secretaries in such regions were denied the latitude afforded the Secretary Dictators, so long as they and their leading cadres abided by the hierarchical ethics of the regional political elite, they were given discretion to pursue initiatives and to build up relationships that could help compensate for the flaws and imperfections of the formal political system.

Rather than mapping career paths and inferring the existence of networks from linked career trajectories, I have used the archival record,

18. Khlevniuk, "Regional'naia vlast'," 33-35.

19. Ibid., 35-37. 
complemented by memoirs and the growing secondary literature, to reconstruct the dynamics of regional networks. ${ }^{20}$ Drawing on a large research project that looked at a sample of twenty-eight regions selected to maximize the variance along a number of key dimensions (including population size, geographical location, socioeconomic structure, and ethnic composition), I have chosen three regions, all from the Russian Federation, which at the beginning of the Brezhnev period corresponded to the ideal types identified by Khlevniuk. ${ }^{21}$ If Kabardino-Balkariia broadly conformed to the first model of a region presided over by a Secretary Dictator, and Kirov approximated the second model of a Weak Secretary region, then Krasnodar provides a textbook example of a "rule-bound network." 22 While it was on the latter model that the other regions would converge as the Brezhnev period wore on, this would, as we shall see, come at a cost.

\section{Kabardino-Balkariia}

In the mid-1960s Kabardino-Balkariia had a modest population of 518,000 and virtually the smallest party organization in the RSFSR (66th out of 70). A decade earlier, the Balkars, whom Iosif Stalin had deported during the war, had been allowed to return and, accordingly, the region reverted to its former title of Kabardino-Balkariia (having been called the Kabardinian ASSR from 1944 to 1957). Despite this, some Balkars, who made up 8 percent of the population, complained of continued ethnic discrimination against them by the Kabardin leadership. In the mid-1960s, the first secretary of the autonomous republic was T. K. Mal'bakhov, a Kabardin and stalwart of the republican political establishment, who had held his position since January $1956 .^{23}$ By the early Brezhnev period Mal'bakhov had become something of a Secretary Dictator.

Key to grasping the elite dynamics of the republic is the fact that Mal'bakhov was not only a Kabardin, but that he came from a particular district, Tersk, and it was from here that he recruited his closest allies and the members of his leadership network. ${ }^{24}$ Among the members of the Tersk circle who were closest to Mal'bakhov were the obkom secretary,

20. Examples of the traditional approach include the excellent books by Michael $\mathrm{E}$. Urban, An Algebra of Soviet Power: Elite Circulation in the Belorussian Republic, 1966-1986 (Cambridge, Eng., 1989); and John P. Willerton, Patronage and Politics in the USSR (Cambridge, Eng., 1992).

21. For a full list of the regions examined, see our project Web site at www .socialsciences.manchester.ac.uk/sovietprovinces (last accessed 1 June 2010).

22. It should be noted that the three regions varied considerably by rank order of their obkom committees. Thus, of the 70 provincial party committees in the RSFSR in 1966, Peter Frank ranked Krasnodar 4th, Kirov 30th, and Kabardino-Balkaria 66th. See Peter Frank, "Constructing a Classified Ranking of CPSU Provincial Committees," British Journal of Political Science 4, no. 2 (1974): 229-30.

23. Mal'bakhov had followed a classic party career in the republic, climbing up the ranks from raikom secretary in $1946-47$ and raikom first secretary in 1947-49, to secretary and then second secretary of the Kabardinian obkom from 1949-52, and chair of the presidium of the republican supreme soviet from 1952-56.

24. Mal'bakhov himself was born in the village of Deiskoe in the Tersk district on 18 November 1917. 
M. Kh. Shekikhachev, the head of the republican trade union organization, Rosa Sabanchieva, the secretary of the Presidium of the Republican Supreme Soviet, F. T. Arsaeva, and the head of the department of construction at the obkom, Pshikan Khapachaev. This Tersk group dominated some of the key strategic positions in the republic. Of the five Kabardins on the obkom buro, three (Mal'bakhov himself, Shekikhachev, and Sabanchieva) were from Tersk, and of the nineteen Kabardin deputies on the Supreme Soviet who held executive positions, twelve, or 63 percent, were from the same district. ${ }^{25}$ The obkom buro met relatively rarely, and its cadre decisions were often ignored or rejected, but Mal'bakhov regularly consulted an informally constituted grouping of Tersk associates on appointments. "I assert," wrote one well-informed insider in a letter to the Central Committee, "that not a single cadre question is decided by comrade Mal'bakhov without the advice of comrades Sabanchieva, Arsaeva, and his other zemliaki [from Tersk]. This is well known to all comrades in the republic."26 Members of the Tersk group also acted as Mal'bakhov's most reliable agents. "They create a cult of Mal'bakhov," reported the same source, "they sow intrigues, organize anonymous letters, and try to frighten those who have the temerity to criticize Mal'bakhov."27 The most assiduous in this regard was the ideology secretary, Shekikhachev, whom Mal'bakhov appears to have used to hound a number of opponents, such as the former obkom secretaries, I. L. Ul'bashev, Ch. B. Uianaev, and $\mathrm{Kh}$. I. Khutuev, as well as various raikom secretaries who had dared to stand up to him. According to K. K. Uianaev: "Strictly speaking, comrade Shekikhachev is not a secretary of the obkom but a personal enforcer [prokuror], and he certainly does not seem to engage in work of an ideological kind." 28

As a Secretary Dictator, Mal'bakhov's power-building strategy rested to a large degree on promoting dependents from his native district. To an outside observer, it may have appeared that these candidates' main qualifications were not their professional or work attributes but their per-

25. Rossiiskii gosudarstvennyi arkhiv noveishei istorii (RGANI), f. 5, op. 61, d. $9,1.31$.

26. Ibid., 1. 34. The author of this letter, K. K. Uianaev, was certainly not a fan of Mal'bakhov's. There are good reasons, however, for taking his communications with the Central Committee seriously. He sent two letters, one on 23 March 1969, to Brezhnev, in response to which the Central Committee party organs department demanded more evidence. A mass of solid, detailed information was then provided in a 14-page letter that the Central Committee received on 28 August 1969. RGANI, f. 5, op. 61, d. 9, 1l. 23-43. On the particular issue of the influence of the Tersk network on Mal'bakhov, years later, in a tribute volume to Mal'bakhov, a former okbom secretary and friend of Mal'bakhov's conceded in coded terms that the former first secretary had been prone to making appointments "under the influence of a certain group" and then added: "Which leader in earlier times was able to escape the influence of his immediate circle? There was probably only one, I. V. Stalin.” M. I. Dokshokov, Glavnaia privilegiia-otvetstvennost' za drugikh (Nal'chik, 1998), 99; and see B. M. Zumakulov, S. N. Beituganov, and V. Zh. Kudaev, Govoril tikho, slyshali vse (Nal'chik, 2000), 30, 350, 352.

27. RGANI, f. 5, op. 61 , d. $9,1.34$.

28. Ibid., 1. 39. For additional evidence, see ibid., 1. 37; and Rossiiskii gosudarstvennyi arkhiv sotsial'no-politicheskoi istorii (RGASPI), f. 17, op. 105, d. 294, 1. 4, and RGASPI, f. 17, op. 103, d. 282, 1l. 26-27. 
sonal connection to Mal'bakhov, a fact that made them highly vulnerable should Mal'bakhov himself have lost office. It was this extreme personal dependence on Mal'bakhov that transformed these individuals from runof-the-mill "colleagues" into Mal'bakhov's "clients." In order to accentuate their dependence on him, Mal'bakhov not only opted for individuals from Tersk but, sometimes quite deliberately, for candidates with personal blemishes or a questionable past. One example was V. Z. Duduev, who, following an extramarital scandal while head of the republican Komsomol, was appointed, against the wish of the obkom buro, second secretary of the Nal'chik (republican capital) gorkom and then head of the capital's Soviet executive committee. "At one of the plenums of the gorkom," recalled K. K. Uianaev, although "members of the gorkom knew that the obkom buro opposed the appointment of Duduev as gorkom secretary, [and] they were exasperated, they objected [oni vozmuschalis, vozrazhali], nevertheless, all the same, comrade Mal'bakhov insisted on dragging Duduev in as the new gorkom secretary." ${ }^{29}$ Wilfully defying the wishes of the aktiv - those rank-and-file officials and party enthusiasts who sat on the gorkom-Mal'bakhov demonstrated his power, converted Duduev into a "client" and brought him into the inner sanctum of the republican political system. Other controversial figures from Tersk who received spectacular promotions, in spite of majority opposition on the obkom buro, were Goriacheva (no initials provided) who became deputy minister of education and M. M. Gukepshev, a relative of Sabanchieva's, who was first installed as chair of the Nal'chik city executive committee before becoming head of the industrial-transport department at the obkom. ${ }^{30}$

At public meetings Mal'bakhov and his allies were unsparing in their attacks on those outside their network. When, at a meeting of the obkom plenum on 5 February 1968, the Minister of Agriculture, M. Kh. Khachetlov, and a candidate member of the obkom, N. F. Mishkov, tried to fend off Mal'bakhov's criticisms, they were sharply rebuffed. Mal'bakhov himself taunted the minister:

MAL'BAKHOV: $\quad$ If I am right, I have understood comrade Khachetlov thus: we mustn't criticize [his] ministry or at the very least we should say that the ministry and the obkom are both at fault here. Is that right?

KHACHETLOV: Yes.

MAL'BAKHOV: $\quad$ Well, tough (laughter in the hall). No, comrades, we shall all the same have to criticize the ministry of agriculture... I take it that the members of the obkom have no problem with this?

VOICES FROM HALL: No, no problem. ${ }^{31}$

As for Mishkov, the minister of health, V. Sh. Shogenova, one of Mal'bakhov's closest confidantes from Tersk, chided: "It has to be said that

29. RGANI, f. 5, op. 61 , d. 9, 11. 39, 30 .

30. Ibid., 1l. 33-34.

31. RGASPI, f. 17 , op. 104 , d. 330,1 . 23. "The criticisms made by comrades Cheremisin, Mishkov, and Khachetlov have no obvious content," Mal'bakhov concluded. Ibid., 1. 24. 
certain members of the party have committed anti-party acts, especially comrade Mishkov."32 Mal'bakhov joined in: "I hadn't thought we needed to out comrade Mishkov. But if it comes to naming names then, of course, we have to start with his first of all." 33 "Mal'bakhov ... starts shouting and is rude and persecutes those who criticize him," K. K. Uianaev noted. "That was the case with the former first secretary of the Zol'skii raikom, Anuar Keshtov [as well as with ... . ] the first secretary of the Urvanskii raikom, Zh. Efendiev [both of whom were] dismissed for [their] troubles." 34

Early in 1968 the Central Committee began to curb Mal'bakhov's hold on power in Kabardino-Balkariia. While falling short of a wholesale purge of Mal'bakhov and his Tersk network, the Central Committee began to strengthen its institutional checks on the republican leader. Until this point, the strategically significant post of head of cadres at the obkom had been held by a Russian, Andrei Mel'nik, who was also a member of the obkom buro. ${ }^{35} \mathrm{Mel}^{\prime}$ nik had enjoyed a good relationship with the deputy head of the department of party organs at the Central Committee, V. I. Bessarabov, and had been used by the latter to keep an eye on appointments in the republic. ${ }^{36}$ But Mel'nik had been outflanked by Mal'bakhov and the Tersk group, who in any case usually bypassed the obkom buro altogether when making decisions on cadres. In February 1968, however, this state of affairs began to change. After twelve years as second secretary, the Tatar, Gennadii Khubaev, who had come to regard Kabardino-Balkariia as his "second homeland" was replaced by a fifty-year-old Russian, Nikolai Krupin, who had spent the previous ten years in the department of party organs at the Central Committee. ${ }^{37}$ Also that February, a third Russian, the new local head of the KGB, Mikhail Timofeev, was voted onto the obkom buro. ${ }^{38}$ With three Russians on the buro, all of whom occupied positions of power within republican administrative structures and all of whom demonstrably enjoyed the support of the Central Committee, the Tersk network was confronted with a powerful counterweight.

A second factor that altered the dynamics of elite politics in the republic was a demonstration-cum-riot at the central kolkhoz market in Nal'chik on 13 July 1968, at which a Russian policeman, who was falsely accused of having beaten two Kabardins to death, was himself murdered by a frenzied mob. ${ }^{39}$ As the crowd began to give vent to anti-Russian senti-

32. Ibid., 1. 22. Emphasis added.

33. Ibid., 1. 24. Mishkov was not nominated for reelection. See RGASPI, f. 17, op. 104, d. $324,11.244-51$.

34. RGANI, f. 5, op. 61 , d. 9, 11. 37-38.

35. See RGASPI, f. 17 , op. 102 , d. $304,11.6-7$.

36. On this and Bessarabov's poor personal relations with Mal'bakhov, see Dokshokov, Glaunaia privilegiia, 119.

37. Krupin's biography can be found in RGASPI, f. 17, op. 104, d. 330, 11. 7-8. For Khubaev's reference to the republic as his "second homeland," see ibid., 1. 10.

38. RGASPI, f. 17, op. 104, d. 330, 1. 29.

39. According to a letter issued two days after the riot, the trouble started when the policeman, V. I. Tokarev apprehended a Kabardin, N. Kh. Maremukov, who, reportedly in an inebriated state, smashed one of the windows in the police office and shouted that he was being beaten to death. At the same time, two other Kabardins, Tkhakakhov and 
ments, Mal'bakhov, who had rushed to the scene, addressed the demonstrators in the local language, Kabardian, and eventually managed to assuage the mob. Mal'bakhov's subsequent efforts to dismiss the disturbance as the work of "hooligans," "speculators," and "criminals" were in vain, however. An internal memorandum two days later acknowledged that the outbreak had been fuelled by ethnic tensions, a view corroborated by a Central Committee report at the end of August. ${ }^{40}$ The affair heightened Bessarabov's sensitivity, not only to relations between Kabardins and Russians, but also to the simmering tensions between the titular nationalities in the republic, the Kabardins and the Balkars, and sharpened his department's attention to the quotas used by the state to regulate relations between the two ethnic groups. ${ }^{41}$ Over a year later, in October 1969, in response to an allegation that Balkars had been purged from leading republican institutions, Bessarabov's department was quick to respond: "At present there are 45,000 Balkars in the Kabardin-Balkariian ASSR, that is to say 8.1 percent of the population, while they make up 8.3 percent of the party organization. They comprise 15.4 percent of the republican supreme soviet and 17.5 percent of members and candidates of the obkom. Among students at the university, 9.7 percent are Balkars." 42

The appointment in 1968-69 of Slavic viceroys and the consolidation of nationalities quotas marked a refinement of long-standing techniques, first developed in the late Stalin era, for managing national relations in the Soviet multiethnic state. ${ }^{43}$ The third institutional check on Mal'bakhov would, however, prove to be the most significant. In summer 1969 the Central Committee took steps to clamp down on Mal'bakhov's Tersk network. At a meeting of the obkom buro in August 1969, Mal'bakhov was forced to attack two of his own dependents, the director of the "Skototkorm" trust, P. A. Shogenov, and the director of the Tersk cattle-fattening sovkhoz, Kh. $\mathrm{Kh}$. Pshigoshev, two individuals whom he had earlier stoutly defended..$^{44}$ The two were dismissed and criminal proceedings were initiated against

Kunizhev, claimed, as it turned out falsely, that Tokarev had also killed Tkhakakhov's brother, Alik. An angry crowd of 2,000-3,000 quickly gathered outside the police station as a vanguard group of rioters caught up with Tokarev, who was attempting to flee by car, and killed him. Most of these facts were confirmed at the trial, which was held in November and December 1968. Three defendants were sentenced to death, six to terms of 12 to 15 years, and a further twenty-four to terms varying from 6 months to 10 years. RGASPI, $\mathrm{f}$. 17, op. 104, d. 336, 11. 93-94, 105-6; RGASPI, f. 17, op. 104, d. 337, 1. 133; and RGASPI, f. 17, op. 104, d. 338, 11. 87, 97-98; also see RGANI, f. 5, op. 61, d. 9, 1. 24.

40. RGASPI, f. 17, op. 104, d. 336, 1. 94; RGANI, f. 5, op. 61, d. 9, 1l. 24, 26.

41. Dokshokov, Glavnaia privilegiia, 98.

42. RGANI, f. 5, op. 61 , d. 9,1 . 42. In fact, it was probably for this reason that even prior to the Nal'chik events Mal'bakhov had been constrained in his ability to remove certain Balkars such as Kh. I. Khutuev and Ch. B. Uianaev altogether from the republican elite so that, although they were dismissed from their republic-level posts, they retained their seats on the obkom.

43. Yaroslav Bilinskii, "The Ruler and the Ruled," Problems of Communism 16 (September-October 1967): 20-21; and John H. Miller, "Cadre Policy in Nationality Areas: Recruitment of CPSU First and Second Secretaries in the Non-Russian Republics of the USSR," Soviet Studies 29, no. 1 (1977): 15, 19-20, 32.

44. RGANI, f. 5, op. 61, d. 9, 1. 29. 
the latter. ${ }^{45}$ In a thinly disguised rebuke of Mal'bakhov, a Central Committee report on Kabardino-Balkariia two months later lamented that "certain party committees have not always responded in a principled way to violations by leading cadres from the republic of party and state discipline." ${ }^{6}$ The tables were now turned on the Tersk network. At the January 1971 obkom plenum Mal'bakhov noted that the Tersk district, previously "famous throughout the North Caucasus" for its agricultural successes, had recently fallen on hard times. ${ }^{47}$

Mal'bakhov was not only structurally hemmed in by his centrally appointed overseers. He was also forced to step back from his earlier brusque and confrontational methods and to observe the standards of decorum that were becoming a feature of Soviet public life. In what could be viewed as a rebuttal of his own former style of leadership Mal'bakhov asserted in 1970: "We cannot entrust a leading position to a person if he cannot be sensitive and attentive to others, if he is not courteous and tactful. . . Those positions that involve dealing with people are not suitable for the hard or callous individual." 48 Hand in hand with this new emphasis on deference went greater respect for authority and for the formal office and level of seniority of an incumbent. "It so turns out," Mal'bakhov would tell the members of his obkom buro in 1972, that "I am more senior than you in terms of age and experience. But I am also more senior in terms of my formal position [starshe $i$ po dolzhnosti]. Of course, this may not be to everyone's liking, but that is the way it is." 49

Rather than unleashing a regional purge of the kind that Stalin or Khrushchev might have favored, Brezhnev's Central Committee drew on the existing repertoire of institutional controls on leaders in the national territories in order to muzzle Mal'bakhov, but it also went beyond these techniques by forcing Mal'bakhov to act against his narrowly constituted territorial network and by requiring him to temper his public persona to fit in with the more restrained norms of the post-Khrushchev leadership. Forced to turn against his Tersk "clients," Mal'bakhov was compelled to broaden the regional ruling elite to include ordinary "colleagues" whose ties to him were more conditional. With this his leadership shed the attributes of the Secretary Dictator and shifted toward the "hierarchical ethics" of Khlevniuk's "norm-bound region." In this form, Mal'bakhov was allowed to stay on as the first secretary of Kabardino-Balkariia until 1985.

\section{Kirov}

Kirov province in the early Brezhnev period had what we may regard as the archetype of a weak leader and a divided elite that had congealed around two rival networks. The obkom first secretary at this time was B. F.

45. RGASPI, f. 17, op. 104, d. 336, 11. 115-17; RGASPI, f. 17, op. 105, d. 295, 1. 36.

46. RGANI, f. 5 , op. 61 , d. $9,1.43$.

47. RGASPI, f. 17, op. 105, d. 295, 1. 129; RGASPI, f. 17, op. 106, d. 306, 1. 105.

48. RGASPI, f. 17, op. 105, d. 295, 1. 42.

49. Zumakulov, Beituganov, and Kudaev, Govoril tikho, 376. Emphasis added. 
Petukhov, who had been parachuted in from the south in February 1961, following the dismissal as first secretary of A. P. Pcheliakov, in one of the most celebrated data-fixing scandals of the era. ${ }^{50}$ As a southerner and an outsider, Petukhov irked some members of the local elite who felt he did not fully understand local conditions. Following a series of fractious disputes, Petukhov found himself faced with a formidable opposition network, which had its base in the obkom bureaucracy.

The origins of Petukhov's Brezhnev-era disputes reached back to the division of the obkom apparatus in November 1962. As first secretary of the more powerful agricultural obkom (Kirov was a predominantly agricultural region), Petukhov embarked on a number of ill-advised policies on procurement levels and on sowing practices that led to a fall in yields and productivity in 1963 . His detractors were quick to blame this on the fact that, as a southerner, Petukhov failed to grasp the different geographic and climatic circumstances of Kirov, a northern region..$^{51}$ On 28 February 1964, Khrushchev launched a broad attack on the Kirov leadership for its poor economic record and on 12 March Petukhov himself was ordered to Moscow and reprimanded. A resolution of the RSFSR Buro of the Central Committee of 13 March 1964 assailed Petukhov for the high turnover of cadres in his region and for a style of work that encouraged "cringing and servility [podkhalimstvo $i$ ugodnichestvo]."52 The resolution was publicized at the following obkom plenum in April, and this paved the way for some sweeping attacks on Petukhov. Two of his sternest critics at the plenum were A.V. Podoplelov and N. P. Chemodanov who, taking their cue from the Central Committee resolution, attacked Petukhov for fostering "servility" (ugodnichestvo) and "nepotism" (semeistvennost'). ${ }^{53}$

In November 1964 the Central Committee received a denunciation of Petukhov, which prompted a second summons to Moscow and, in turn, a new round of hostile articles in the Kirov regional paper, Kirovskaia pravda ${ }^{54}$ At the December 1964 plenum, which was charged with electing a reunited single obkom, one of Petukhov's critics from April, Podoplelov, embarked on an all-out attack on Petukhov for "not tolerating objections, overestimating his own abilities" and surrounding himself with "people who flatter and cringe"; others, meanwhile, attacked Petukhov for fostering "toadies," for cultivating "cringing and servility" and for being no less to blame for the woeful state of agriculture in the region than the now universally maligned former First Secretary of the Central Committee,

50. Petukhov had studied in Rostov and served for almost a decade in senior party and state positions in Krasnodar and North Ossetia. For more on Pcheliakov, see Yoram Gorlizki, "Scandal in Riazan': Networks of Trust and the Social Dynamics of Deception" (unpublished paper, 2009).

51. RGASPI, f. 556, op. 10, d. 588, 11. 48, 80. In June 1963 Petukhov also organized a highly controversial economic conference that reportedly descended into a celebration of Petukhov's own "teachings" on the economy. See ibid., ll. 21-23, 78.

52. RGASPI, f. 556, op. 10, d. 588, 11. 1-3, 21-22, 78; and RGANI, f. 5, op. 61, d. 8, 11. $128,107$.

53. RGASPI, f. 556 , op. 10 , d. 588 , 11. $46-49,54-55$.

54. RGASPI, f. 556, op. 14, d. 243, 11. 170-71; and RGASPI, f. 556, op. 10, d. 596, 1. 112. 
Nikita Khrushchev. ${ }^{55}$ At the closed obkom ballot, 53 of the 491 delegates voted against Petukhov, and his closest supporters also attracted heavy protest votes. ${ }^{56}$ Although Petukhov was eventually elected as first secretary of the united obkom, his authority was dented.

Shortly after the reunification of the obkom, a new opposition to Petukhov formed within the obkom buro. Podoplelov, now an obkom secretary, and Chemodanov, now head of the cadres department, were joined by two other disgruntled figures, the new second secretary of the obkom, P. G. Dobroradnykh (formerly the first secretary of the industrial obkom), and the new agricultural secretary, I. M. Kolupaev (the former second secretary of the agricultural obkom). While other members of the buro rallied round Petukhov, this group remained staunchly opposed to him. As a candidate member of the buro, Iu. G. Karacharov, later recalled: "If the first secretary says 'yes,' this group always sa[ys] 'no.' "'57 Petukhov would himself concede afterwards that "within the buro there practically existed two buros ... with the second buro consisting of comrades Dobroradnykh, Podoplelov, Kolupaev, and Chemodanov. ... [Prior to meetings of the buro, the four would get together at] comrade Dobroradnykh's house to debate the points and would then turn up at the buro to declare: 'We are against." ${ }_{58}$ On one occasion Petukhov, in the presence of an instructor from the Central Committee, warned Dobroradnykh to "stop organizing a second buro." 59

Against stern resistance, Petukhov did manage to have his main opponent, Dobroradnykh, dismissed. There ensued, however, a particularly bitter standoff between Petukhov and the head of cadres at the obkom, Chemodanov. As in any obkom, the cadres department was the most important instrument of network building in the region and Petukhov regarded control of it as an absolute priority. For their part, his detractors, including Dobroradnykh, who remained a member of the obkom, charged Petukhov with treating "the department of party agencies [that is, the cadres department] as . . . his own fief." ${ }^{60}$ Petukhov countered by accusing Chemodanov of being "insubordinate" and of having "false ideas of his own importance." ${ }^{61}$ I. P. Bespalov, who in 1968 became the second secretary of the obkom, remarked: "Although the [head of the] orgotdel is subordinate to the first secretary, Chemodanov has always seen himself as

55. RGASPI, f. 556, op. 10, d. 596, 11. 63-65, 78-79, 93, 97. One of Petukhov's most ardent former supporters, the obkom secretary A. V. Smirnov, now switched sides and also began to criticize Petukhov. See ibid., 11. 73-75.

56. Those with the highest protest votes (30 and over) were the senior officials from the former agricultural obkom, V. P. Liamov, E. N. Nekrasov, and E. A. Rodin, who had stood by Petukhov in the debates of 1962 to 1964. See RGASPI, f. 556, op. 10, d. 588, 11. 23, 80-81; RGASPI, f. 556, op. 10, d. 596, 11. 24-25, 79, 93; also see Michel Tatu, Power in the Kremlin: From Khrushchev's Decline to Collective Leadership (London, 1969), 436.

57. RGANI, f. 5, op. 61, d. 8, 1. 115.

58. Ibid., 1. 118.

59. Ibid., 1. 120.

60. Ibid., 11. 123-24.

61. Ibid., ll. 85, 119. 
the first secretary's equal." ${ }^{62}$ For a long time, Bespalov noted, Chemodanov "has neglected to go and see the first secretary to decide important questions. He seemed to reckon that people had to go cap in hand to see him." Another member of the buro, Vorob'ev, noted "that over the course of two whole years [Chemodanov] could not spare five minutes to go and see the first secretary to sort out various questions, what sort of behavior is this?" 63 Although Petukhov did manage, eventually, to have Chemodanov removed from the obkom buro in mid-1967, an attempt in early 1968 to have him fired as head of the cadres department was aborted. ${ }^{64}$

Petukhov's two remaining adversaries on the buro, Podoplelov and Kolupaev, continued to defy him. One buro member, Grachev, stated that "comrades Podoplelov and Kolupaev cannot stomach the first secretary. They simply cannot stand him. They use every opportunity to discredit him and have him removed. . . O Over a number of years now they have followed a separate line from the buro on a variety of key cadre questions." 65 In the meantime, two regional scandals further polarized the regional elite as a number of disaffected officials gravitated toward the Chemodanov-Podoplelov-Kolupaev camp. ${ }^{66}$

Matters eventually came to a head in the summer of 1969. In April Petukhov appeared to have finally secured the transfer of Chemodanov from the obkom cadres department to a secondary office at the ispolkom. When Petukhov asked for the decision to be ratified at the meeting of the full obkom on 24 June, however, he came in for something of a shock. Before an enlarged audience that included Komsomol members and pensioners who were not members of the obkom, the decision was challenged, first by Podoplelov, then by Chemodanov himself, as well as by Kolupaev, and a number of disenchanted officials, such as Liamov, and the former obkom secretary, Dobroradnykh. In a series of pointed attacks, and much to the astonishment of the invited audience, the dissenters reprised a host of grievances against Petukhov and accused him of stifling criticism, trampling on local democracy, participating in political intrigue, and engaging in a pattern of abuse and vindictiveness. ${ }^{67}$ In an outburst strongly resonant with the attacks on Petukhov during the late Khrushchev period, Chemodanov accused Petukhov of "surrounding himself with cringers and servile individuals [podkhalimami $i$ ugodnikami] who constantly praise and admire him." 68

62. Ibid., 1. 103.

63. Ibid., 1l. 76, 82. Emphasis added.

64. Ibid., 11. 82, 94 .

65. Ibid., ll. 84-85.

66. The two main flashpoints were the so-called Nolinskii Affair, after which the former head of the oblispolkom, A. V. Smirnov, was sacked, and a tragedy at the local sports stadium on 25 May 1968, when 39 people were killed. The stadium tragedy forced Petukhov to take action against a number of local officials such as Zaporozhskii, Liamov, and Kolbin, following which the latter two refused even to greet or acknowledge him in public. RGANI, f. 5, op. 61, d. 8, 11. 81, 86, 97, 100-101, 107, 117, 119.

67. Ibid., 11. 94-99, 106-9, 123-25. The latter criticisms were voiced in closed session.

68. Ibid., 1. 96. 
At first, this collective attack caught the first secretary and his followers unawares. As the meeting progressed, however, a number of Petukhov's followers on the buro, as well as members of the aktiv, rallied to his defense. The retaliation was more clearly formulated at a meeting of the obkom buro the following week, on 30 June. Throughout the regional party organization there was now a groundswell of opinion in support of Petukhov and his office. The dissidents had, according to the buro member Derevskoi, "undermined the authority [avtoritet] of the first secretary and of the buro as a whole." ${ }^{69}$ Another buro member, Karacharov, invited the others to imagine the following scenario: "Let's say that you, as the first secretary say one thing, while your head of department says something else, then, without doubt, you, as the first secretary, would immediately get rid of him. No first secretary can tolerate a person on the obkom apparatus who does not fall in line and fulfil his duties." 70 The clamor for restoring the authority of the buro sounded as strongly from below, from among the raikom officials, as it did from Petukhov's peers. "Many of the [district] secretaries are telling me," admitted Grachev, "what's up with you [in the obkom buro], you really should be setting an example, why can't you bring the buro to order?"71 When Petukhov's detractors accused him of framing the former head of the ispolkom, Smirnov, the first secretary of the Verkhnekamskii raikom, Bryzgalov, sprang to Petukhov's defense: "[Smirnov was fired] and not before time . . . It's another matter on whose initiative. It may have been Boris Fedorovich [Petukhov] or someone else who came up with the proposal, but in all honesty it should have been his call. What kind of obkom secretary is it who does not show initiative? You [that is, the dissidents] want to put the first secretary in an impossible position. If you had things your way, we raikom first secretaries would also have to cope with this kind of situation. The first secretary has always been and always will remain the first secretary."72

At the June meetings the dissident group were accused of having "violated party ethics." ${ }^{73}$ As a reaction to the public hectoring of the Khrushchev years, new strictures had been implemented on keeping up appearances and on pressing disagreements behind closed doors. "Did you see how many members of the Komsomol were present, how many young people there were who view the buro as a model? Pensioners were invited, but you still could not find it in yourself to announce that you had something to say, but that you would leave it to the closed plenum," remarked the buro member Sharov at the meeting of 30 June. ${ }^{74}$ "It is simply pain-

69. Ibid., 1. 82.

70. Ibid., 11. 114-15.

71. Ibid., 1. 86. "After our conversations," Petukhov himself recounted, "raikom secretaries often come up and tell me that comrade Kolupaev is pestering them: 'How can we keep comrade Petukhov, look at what he is up to.' I'm simply embarrassed for you [Kolupaev] and embarrassed, too, [for them]." Ibid., 1. 122.

72. Ibid., 1. 129. Emphasis added.

73. See speech by Sharov and the letter from Petukhov to the Central Committee of 30 June 1969. Ibid., ll. 89, 68.

74. Ibid., 1. 89. 
ful to hear how obkom secretaries [that is, Podoplelov and Kolupaev] could behave like this," declared another member of the buro, Grachev. "The party has a number of pragmatic principles for assigning cadres. No one holds on to a post forever; if an issue is settled collectively, then for the disciplined party member that really should be it." 75 There was also a wholesale rejection of the linguistic tropes of the late Khrushchev era. "The word toady has an absolutely clear meaning," responded the buro member Vorob' ev. ${ }^{76}$ "We cannot go around pinning the label 'toady' on to all and sundry," Petukhov pitched in. "This is an old, dirty weapon [eto staroe, griaznoe oruzhie]."77

Following the obkom buro meeting of 30 June, Chemodanov's dismissal was confirmed, and both Podoplelov and Kolupaev were sacked as regional party secretaries. With this, the faction that had stuck like a thorn in Petukhov's side since 1962 was at last removed. When Petukhov did eventually step down in 1971, his replacement was a local cadre, the second secretary, I. V. Bespalov, whose appointment accorded with the regime's new policy of promoting local officials and adhering to rules of seniority. In accordance with the pattern of promotion in this period, Bespalov had risen progressively up the hierarchy and was at the time of his appointment one step below Petukhov on the regional nomenklatura ladder.78

Under Petukhov Kirov had exhibited all the hallmarks of Khlevniuk's archetypical "Weak Secretary" region. Accused of being excessively "soft" and "liberal," Petukhov was unable to exercise his prerogatives and effect key cadre changes, including those that by rights lay within his jurisdiction. ${ }^{79}$ As in Kabardino-Balkariia, what the center sought was a broad based leadership network rather than one that was, in this case, divided. To achieve this it capitalized on the authority-enhancing norms that, paralleling trends in Moscow, had taken root among the rank and file in Kirov. With the consolidation of a local, incremental, system of promotion, the Kirov leadership began to edge, like Kabardino-Balkariia, toward Khlevniuk's model of a "norm-bound network." The ideal in this model of a "strong" but restrained leader who was willing to show "initiative" was in keeping with the tenor of Brezhnev's campaign for "trust in cadres." To understand

75. Ibid., 1. 113. "Is it really the case that you can hang on to this post until the end of your days?" the chair of the Iskra kolkhoz asked Chemodanov. "That is not the way of the party." Ibid., 1. 129.

76. Ibid, 1. 111.

77. Ibid, 1. 121. Emphasis added. Podoplelov had also used the term in the RSFSR Soviet controversy, which led to his censure on 31 January 1967, see ibid., 1. 70.

78. Bespalov had risen up through the ranks, serving as first secretary of the Kirov gorkom from 1964 to 1968 and then as obkom second secretary from 1968 to 1971.

79. Petukhov was chided by some local party leaders for his excessive "softness" and "liberalism." RGANI, f. 5, op. 61 , d. $8,11.85$, 88. It was perhaps a measure of this that Liamov was the only person in his eight years as obkom first secretary to receive a formal reprimand (zygovor) from Petukhov. Ibid., 11. 117, 122. "I have no means of influence other than oral reproof [vnushenie]," Petukhov later complained. "The director [of a factory] can issue a written reprimand, but we here [at the party] have to decide things collegially." Ibid., l. 120. 
more fully what this meant in practice we turn to a case study that, from the first, exemplified all the characteristics of a "norm-bound network."

\section{Krasnodar}

Krasnodar provides an example of a powerful first secretary, Grigorii Zolotukhin, who may be viewed as the bearer of a new Brezhnevite ethos in regional affairs. As a strong first secretary, Zolotukhin quickly imposed his stamp on the region and was able to effect cadre changes at the lower levels with a minimum of fuss. But Zolotukhin was never allowed to become a Secretary Dictator. As with Brezhnev himself, Zolotukhin's authority was held in check by a number of institutional controls. ${ }^{80}$ At the regional level, these included significant restrictions on his powers of patronage over senior and middle-level officials, as appointments now complied with a finely graded system of promotion by "seniority." 81 In line with the new arrangements in Moscow, Zolotukhin keenly observed rules of propriety and decorum in dealings with subordinates. ${ }^{82}$ In Krasnodar these policies were presented, not least by Zolotukhin himself, as reflecting a broader commitment to "trust in cadres."

In addition to being the fourth largest region in the Russian republic, Krasnodar was a major producer of grain, supplying one-thirteenth of all grain in the RSFSR in $1966 .{ }^{83}$ Zolotukhin, who became first secretary in January 1966, had earlier served for eleven years as first secretary in Tambov, also a predominantly agricultural region, and was regarded as a heavyweight politician with excellent contacts in Moscow. ${ }^{84}$ Around this time Zolotukhin joined Brezhnev's "rapid reaction force" of regional lead-

80. Commenting on the new arrangements in Moscow, Rigby wrote: "Khrushchev's successors have acquiesced in the emergence of a 'pecking order' in the oligarchy with Brezhnev as No. 1. . . At the same time, however, and this is the most salient characteristic of their style of government, they have hedged the power and authority of individual leaders around with a number of quite formidable controls." Rigby, "Soviet Leadership," $186-87$.

81. For a broader discussion of the "seniority principle" under Brezhnev, see T. H. Rigby, "The Soviet Regional Leadership: The Brezhnev Generation," Slavic Review 37, no. 1 (March 1978): 23; on the "clear unwritten rules" about who could become a regional first secretary under Brezhnev, see Gorbachev, Zhizn' i reformy, 1:122.

82. "Brezhnev," notes one biographer, "was able to get on with people, he never blew up at subordinates but would criticize them gently. His son-in-law Churbanov even thought up the term 'Brezhnevite criticism.' [Churbanov] wrote: 'Leonid Ilich was able like no one else to take people to task without ever offending them." B. V. Sokolov, Leonid Brezhnev: Zolotaia epokha (Moscow, 2004), 206.

83. RGASPI, f. 17, op. 103, d. 469, 1l. 182-84; Frank, "Constructing a Classified Ranking," 229 .

84. As first secretary in Tambov, Zolotukhin had emerged as a leading light of a formidable group of "agricultural first secretaries" against whom, on some accounts, Khrushchev's 1962 bifurcation had been directed, and for which reason this group had inclined strongly toward Brezhnev in October 1964. See John A. Armstrong, "Party Bifurcation and Elite Interests," Soviet Studies 17, no. 4 (April 1966): 422-24, 426-27. In Tambov Zolotukhin had come to know the then first secretary of the nearby Ivanovo obkom, Ivan Kapitonov, and it was Kapitonov who, having recently been installed as Central Committee secretary in December 1965, unveiled Zolotukhin as the new leader of Krasnodar at a Kraikom meeting on 12 January 1966. RGASPI, f. 17, op. 102, d. 499, 1. 57. 
ers who were regularly given the floor at party plenums and congresses. ${ }^{85}$ At the Twenty-third Party Congress in March 1966, Zolotukhin was duly elected as a full member of the Central Committee. In the coming years, it was taken as a reflection of Zolotukhin's considerable clout in the capital that he could boast of major over-the-plan increases in investment by the central government in his region. ${ }^{86}$

Zolotukhin's appointment in Krasnodar was typical of the light Brezhnevite purge of regional officials that took place soon after Khrushchev fell. Zolotukhin replaced G. I. Vorob'ev, whose authority had earlier been eroded by a series of scandals. ${ }^{87}$ Diminutive, and with a slightly twisted face, Zolotukhin, nicknamed the "Tambov wolf," was quick to make his mark and, in the words of one commentator, "did not leave any member of his circle in any doubt as to who was in charge of the Kuban." ${ }^{88}$ In January 1967 Zolotukhin effectively cleared out eight raikoms, removing not only the first secretaries but the second secretaries as well as the ordinaryrank secretaries in each case. ${ }^{89}$ During 1967 Zolotukhin also ordered investigations and plenum debates on the strategic party organizations in the region, including the Krasnodar gorkom and the Adygei obkom. ${ }^{90}$ But the most incisive criticisms were of the gorkom of the third city in the krai, Novorossiisk, which eventually led to the sacking of its first secretary, N. E. Tupitsyn, on 13 May 1967. ${ }^{91}$ Zolotukhin was also eager to pass along the economic demands imposed on him by Moscow to his subordinates, by singling out and publicly humiliating those plant managers and kolkhoz chairs who failed to meet their plan targets. ${ }^{92}$ As Zolotukhin was wont to remind officials, he was not afraid to take "organizational measures" (orgvyvody) where need be, as he did in 1966 when he fired the director of the Krasnodar house construction industrial complex, V. D. Kiriakin, for "having made numerous promises on the construction of buildings, all of which were broken." 93 To observers in neighboring regions, such as the

85. Gorbachev, Zhizn' $i$ reformy, 1:140-41. Although Gorbachev, who was partial to Zolotukhin, does not explicitly include him in this group, it is clear from his description and from Zolotukhin's role at numerous congresses and plenums that he was a member. See, for example, N. G. Egorychev, Politik i diplomat (Moscow, 2006), 160.

86. Thus in November 1968 Zolotukhin announced major over-the-plan allocations of tractors, manure, agricultural machinery, and means of transport to Krasnodar. RGASPI, f. 17, op. 104, d. 536, 11. 272-73.

87. See Viktor Saloshenko, Predsedateli i gubernatory: Vzaimosviaz' vremen (Krasnodar, 2002), 399-400.

88. Ibid., 374.

89. RGASPI, f. 17 , op. 103 , d. 472 , 11. 54-58.

90. See RGASPI, f. 17, op. 103, d. 474, 11. 139-44; RGASPI, f. 17, op. 103, d. 477, 11. 306-9. As a krai, Krasnodar encompassed an obkom-level administrative unit, the Adygei autonomous oblast.

91. This followed a series of carefully orchestrated attacks on Tupitsyn, especially at the kraikom buro on 9 August, and at the kraikom plenum on 19 September, which progressively sapped Tupitsyn of his authority. See RGASPI, f. 17, op. 102, d. 504, 1. 125; RGASPI, f. 17, op. 102, d. 500, 1l. 40-41; RGASPI, f. 17, op. 103, d. 474, ll. 80, 91.

92. See especially RGASPI, f. 17 , op. 105 , d. 480 , 1. 47, but also RGASPI, f. 17, op. 103 , d. 469, 1. 189, and RGASPI, f. 17, op. 104, d. 536, 1. 282.

93. For the Kiriakin affair, see RGASPI, f. 17, op. 102, d. 500, 1. 42; on other "organizational measures," see RGASPI, f. 17, op. 105, d. 479, 1. 192; RGASPI, f. 17, op. 105, d. 480, 1. 54; RGASPI, f. 17, op. 103, d. 469, 1l. 190-91; and RGASPI, f. 17, op. 105, d. 479, l. 192. 
young Mikhail Gorbachev in Stavropol', news soon filtered through that Zolotukhin was "on the case" in Krasnodar. ${ }^{94}$

Zolotukhin's shows of strength were nonetheless carried out within clearly prescribed parameters. Although he could readily dismiss raikom secretaries, there were constraints on his powers of patronage. With regard to middle-level and senior appointments Zolotukhin was forced to respect the ladders of promotion within the region. In contrast to the Khrushchev period, which had seen massive promotions of cadres over the heads of their immediate superiors, as well as the regular appointment of outsiders, Zolotukhin complied with the "seniority principle" whereby promotions were incremental and made from within the province. ${ }^{95}$ All of his appointments to the kraikom buro were of senior long-standing regional officials whose previous posts had been one step below on the regional nomenklatura. ${ }^{96}$ In a manner that paralleled the institutional limits on Brezhnev's control of high-level cadres in Moscow, Zolotukhin was compelled to be quite conservative in his leadership appointments. ${ }^{97}$ Further, much as in Kabardino-Balkariia and Kirov, Zolotukhin insisted on behavioral self-restraint among cadres. Distancing his approach from the "boorishness" and "petty tyranny" of the Khrushchev era, Zolotukhin urged cadres to refrain from unnecessary shouting, swearing, and bullying. Six months after Brezhnev's speech at the Twenty-third Party Congress, Zolotukhin declared: "High expectations have nothing in common with bellowing, ordering people about and running things in an administrative way. Holding functionaries to account should not mean yelling, shooting off punishments, or blowing up at people. . . High expectations need to be matched by trust and respect - this is one of the most important principles of the cadre policies of our party, and this needs to be strictly enforced in real life."98

In the period shortly after Brezhnev's speech, the term trust was often used in this rather formulaic phrasing in tandem with, and as a synonym for, respect, that is, as deference toward officeholders. "Trust" also acquired a more concrete meaning, however. In order to grasp this, we need to recall that one of the main policy shifts of the early Brezhnev period was a disavowal of the party's day-to-day administrative involvement in the economy and an upgrading of its ideological functions. This was

94. "Through his strictness, high expectations, [and] personal asceticism . . . Zolotukhin was quick to bring order to this huge region," writes Gorbachev. See Gorbachev, Zhizn' i reformy, 1:139.

95. On this contrast between the Khrushchev and Brezhnev periods, see Afanasy Federovich Eshtokin: Lichnost' gosudarstvennogo masshtaba (Kemerovo, 2000), 86.

96. This applied to Albert Churkin, Sergei Medunov, A. A. Khomiakov, O. S. Nikitiuk, and N. A. Ogurtsov. At the lower levels too, the "seniority principle" was closely adhered to. Thus, all eight of the new raikom first secretaries appointed in January 1967 climbed one rung up the nomenklatura hierarchy. RGASPI, f. 17, op. 103, d. 472, 11. 54-56.

97. As with Brezhnev, he had to wait nearly three years, until February 1969, before he could replace any of his obkom secretaries, in this case one who was in any case due to retire, or tamper with the composition of the obkom buro. RGASPI, f. 17, op. 105, d. $478,11.4-5$.

98. RGASPI, f. 17 , op. 102 , d. $500,1.108$. 
presented as a departure from the "petty tutelage" and "incompetent interference" of the Khrushchev years and a move toward so-called political leadership. ${ }^{99}$ So long as the party paid due attention to their selection and political training, cadres should be given greater discretion in everyday operational affairs. ${ }^{100}$ In Krasnodar, Zolotukhin presented this in terms of the language of "trust." "Following the October [1964] Central Committee plenum and the Twenty-third Party Congress," Zolotukhin announced on 19 September 1966, "an atmosphere of trust ... has been established in the party. Nothing now prevents leaders at all levels from working creatively and from demonstrating their independence and initiative."101 Zolotukhin's most detailed elaboration of the notion of trust would come three years later, in December 1969.

Certain comrades recall the times when there used to be what they refer to as "order" and, in essence, they suggest that we return to the tough administrative methods of the past. But such solutions are no longer feasible. The discipline that rests only on fear is not the sort of discipline we need. And this is not only because it would run against Leninist principles of socialist democracy or because it might undermine legality. We must look at the past in a sober light, and not lay it on thick, not idealize what happened. We well remember what the fear instilled by administrative methods led to. It led to dishonesty, to suppressing the real state of affairs, to attempts to bury problems rather than to properly grasp and solve them, it led to deception and falsification. It also led to overinsurance and to the loss of initiative. Today our party is building its approach to cadres on the basis of trust ... for our party and economic cadres have shown that they have the ability to solve complex problems for themselves. ${ }^{102}$

Zolotukhin appeared to recognize the limitations of the purely formal mechanisms - the "administrative methods"- of the past. In order to achieve their goals, cadres should be freed from coercive controls and allowed to show discretion. So long as they complied with the ideological tenets of party rule and observed the post-Khrushchev norms of hierarchical ethics, officials were encouraged to demonstrate greater independence and initiative.

The problem for Zolotukhin was that although he presented "trust" as a signal to show greater initiative, officials interpreted it as a license to engage in informal practices based on personal relationships. One telling

99. As Brezhnev admitted in a speech to Leningrad officials in July 1965: "For 22 years I was an obkom [and republic-level] secretary ... but I would never have said or say now that I somehow 'managed' industry. What nonsense! . . The task of managing and running industry can be undertaken only by those who fully understand this area." General' nyi sekretar' L. I. Brezhnev, 37-38.

100. An important step in this direction was supposed to have been made with the famous July 1965 Central Committee resolution, "On Serious Shortcomings in the Work of the Khar'kov Oblast Party Organization in Admissions to the Party and the Training of Young Communists," originally discussed in Tatu, Power in the Kremlin, 500-502.

101. RGASPI, f. 17, op. 102, d. 500, 1. 101; and see his speech of December 1967 in RGASPI, f. 17, op. 103, d. 477, 1. 309.

102. RGASPI, f. 17, op. 105, d. 480, 1. 53. Emphasis added. 
example was the emphasis now placed on oral commands and agreements as opposed to instructions in written form. In June 1966 the powerful first secretary of the Sochi gorkom, Sergei Medunov, told the kraikom plenum: "The word of the party functionary is objective and truthful and does not need to be supported by a [written] form. We need to take our cue here from the Central Committee, whose instructions are often sealed with a conversation on the phone and perhaps a scribbled note [to this effect]." 103 A further means of consolidating personal relationships under cover of the trust campaign was the establishment of separate sociability networks that went beyond the immediate reach of the state. In a major attack on "personal familiarity" (panibratstvo) among officials in June 1969, Zolotukhin condemned those

leaders [who] base their relations with subordinates not on businesslike party principles but on personal devotion. They support and egg on toadies and bootlickers who know how to organize a get-together, a drinking session (and not, it should be added, at their own expense). Cozy circles are formed in which each member stands solidly behind the other . . . at these drinking sessions, people blurt out whatever comes into their head, they gossip and natter about all and sundry, no less than would a bazaar trader. Frequenters of these drinking sessions and those with long tongues even have their own "clubs," for example the restaurant Ogonek in Krasnodar Park. You surely understand, comrades, that we must do away with these adverse tendencies. ${ }^{104}$

While Zolotukhin presented "trust" as permission to show discretion, some officials apprehended it as a green light to fulfil their newly assigned tasks on the basis of personal relationships. Although reliance on reciprocal relations of this kind had always played a part in enabling Soviet officials to attain their formal objectives, the campaign for "trust in cadres" in effect integrated these practices into the official ideology, thus giving them a new, powerful impetus.

Sometimes, as in the economic realm, this could have damaging consequences. In Krasnodar in the late 1960s we encounter evidence, not only of the "informal practices" described by Joseph Berliner as an indispensible complement to the planning apparatus, but of reciprocal obligations openly undercutting the formal planning mechanism. ${ }^{105}$ In a speech in December 1969 Zolotukhin lambasted local officials who had authorized the construction of administrative buildings, stadiums, pools,

103. RGASPI, f. 17, op. 102, d. 500, 11. 57-58. Emphasis added.

104. RGASPI, f. 17 , op. 105 , d. $479,1.191$.

105. On "informal practices" see, most famously, Joseph Berliner, Factory and Manager in the USSR (Cambridge, Mass., 1957), chaps. 11 and 12. Not all informal devices for achieving cooperation qualify as trust relationships. Some of the economic practices described in this paragraph are perhaps more akin to the "pre-trust relations" of traditional communities, where cooperation is achieved not through self-standing personal relationships but by means of communal norms backed by sanctions. Here, as later, we accept that the "trust in cadres" campaign gave legitimacy to a variety of informal practices, not all of which were trust-based. See Karen S. Cook and Russell Hardin, "Norms of Cooperativeness and Networks of Trust," in Michael Hechter and Karl-Dieter Opp, eds., Social Norms (New York, 2001), 327-47; and Karen S. Cook, Russell Hardin, and Margaret Levi, Cooperation without Trust? (New York, 2005), chap. 5, esp. 91-92. 
and other projects that had patently not been envisaged in the plan. In the Timashevskii district, the construction of a bonemeal plant had been stopped while the building of an unplanned sports complex for 240,000 rubles was, in his words, "proceeding at breakneck speed."

This construction has not been included in any of the plans; no money has been allocated to it. It is simply that the raikom has laid under tribute [oblozhil dan'iu] all the district organizations and enterprises, sometimes for 2-3,000 rubles, sometimes for more. Even from the district finance department they have been able to extract a quit-rent [obrok] to the tune of 1,000 rubles. . . . I don't want the comrades to get me wrong. We are all for stadiums and public welfare projects, but only when they are necessary, when we really can't do without them and certainly only through the proper channels. ${ }^{106}$

Beneath the surface there were yet more sinister developments. In the late 1960s there was an upsurge in cases of embezzlement in the region. ${ }^{107}$ Strikingly, Zolotukhin's most senior appointments, Sergei Medunov, who became head of the kraiispolkom in March 1969, and Albert Churkin, who became second secretary in June that year, would become associated with the acceptance of backhanders and the abuse of office. Many years later, under Gorbachev, Medunov would emerge as one of the bêtes noires of the reform movement and as a symbol of the moral failures of the Brezhnev administration for his alleged record of bribery and malfeasance in Krasnodar. ${ }^{108}$ As for Churkin he was eventually charged with involvement in a major bribery scandal and, following the sudden termination of his career in 1974, was subjected to party punishment for "criminal abuses" in January $1976 .{ }^{109}$

\section{Too Much Trust}

Despite his reputation as a laissez-faire leader, Brezhnev was a firm believer in traditional party-based controls. By the end of his first year in office, he had fully restored the "party vertical," a single, party-based chain of command linking the Central Committee, the obkom, and the raikom, and he wielded his power as first secretary to push through a discreet,

106. RGASPI, f. 17 , op. 105 , d. $480,1.51$.

107. RGASPI, f. 17, op. 105, d. 479, 1l. 192-93.

108. According to the lawyer Arkadii Vaksberg "thousands of letters had been sent to the Kremlin in Moscow ... [and] each of these spoke of law-breaking, extortion, misappropriation of state property, summary justice to anyone that crossed the authorities, and in every letter the finger of guilt pointed at Medunov." Arkady Vaksberg, The Soviet Mafia (London, 1991), 11; also see 16-17, 34-35, and, for a more detailed description of the so-called Medunov clan, see 52-61.

109. According to P. A. Rodionov, a candidate member of the Central Committee from 1966 to 1971, "rumors of Churkin's corruption had been doing the rounds since his time as head of the [Krasnodar industrial] executive committee"; eventually 765,000 rubles were reportedly found on Churkin following a major scandal in 1971. See G. V. Ivanova, ed., Ot ottepeli do zastoia (Moscow, 1990), 205-6. Although Churkin was not prosecuted, his career ended abruptly in 1974, and he was subjected to disciplinary proceedings by a decision of the Committee of Party Control on 28 January 1976: "On the Criminal Abuses of the Former Secretary of the Georgian Central Committee, Churkin A. N." 
scandal-free purge of some of the most powerful provincial leaders in the Russian Federation. ${ }^{110}$ In addition, Brezhnev authorized the famous resolution on the Khar'kov party organization of July 1965 that condemned the apparatus's poor training and lax admission practices, leading to a steady fall in new members and to a sharp rise in expulsions across the country. ${ }^{111}$ Yet the traditional institutional levers of party control, such as crackdowns on party discipline, the instigation of mini-purges, or the relaying of central directives through regional party organizations, were in themselves not enough to bind party officials to a common program or to shore up the credibility of the regime. Following the turmoil of the Khrushchev years, many regional aktivs threw their weight behind a package of authority-enhancing norms that included public shows of deference, the hiding of policy differences, and a carefully calibrated system of seniority based on incremental, step-by-step, promotions. ${ }^{112}$ It was against these norms that in the late 1960s the first two models of regional network described in this article, as exemplified by Kabardino-Balkariia and Kirov, collided. Both regions underwent a shift toward the third model of a norm-bound network where the system of hierarchical ethics found its fullest expression. My hypothesis is that it was toward this latter model of leader-network relations that most regions gravitated as the Brezhnev period wore on.

When the Brezhnev leadership spoke of "trust" (doverie) what they had in mind did not correspond exactly to the concept of trust as it is elaborated by comparative historians and social scientists. The idea, for example, that a centralized regime could launch a "campaign" for trust would strike most observers as odd. Trust tends to grow from the bottom up, out of ongoing social relationships; attempting to induce it through downward pressure or organizational design might well have the opposite effect. ${ }^{113}$ The campaign for "trust in cadres" was, however, quite distinctive. Rather than relying on new or existing structures, the thrust of the whole campaign was that "administrative measures" had been discredited

110. In his first fifteen months, Brezhnev appointed new first secretaries to four of the five largest regions in the RSFSR (Moscow, Rostov, Gor'kii, and Krasnodar), as well as new leaders to some of the most powerful of the other provinces in the republic. New appointments in Moscow (V. I. Konotop), Rostov (M. S. Solomentsev), and Stavropol' (L. N. Efremov) were made on 16 and 18 January 1965, while the new assignments to Cheliabinsk (N. N. Rodionov), Volgograd (L. S. Kulichenko), Gor'kii (K. F. Katushev), and Krasnodar (G. S. Zolotukhin) were made on 16 and 29 November 1965 and 14 and 28 January 1966. The term party vertical is used by R. G. Pikhoia, SSSR: Istoriia vlasti 1945-1991 (Moscow, 1998), 273-74.

111. The average annual number of candidates admitted to the party fell from 760,000 in 1961-1966 to 600,000 from 1966 to 1971. Expulsions rose from 30,300 in 1965 (roughly the average for the previous five years) to 61,900 in 1966 , climbing to 75,800 in 1970. See XXIV S"ezd Kommunisticheskoi partii Sovetskogo Soiuza, 30 marta-9 aprelia 1971 goda. Stenograficheskii otchet, vol. 1 (Moscow, 1971); and RGANI, f. 77, op. 1, d. 12, 11. 217, 217ob.; RGANI, f. 77, op. 1, d. 13, 11. 9, 9ob.; RGANI, f. 77, op. 1, d. 14, 11. 78, 78ob.

112. In order to make room for these practices Brezhnev virtually abandoned crosspostings between regions and radically reduced the appointment of central officials to the non-national territories. XXIV S"ezd, 1:124.

113. On this, see Gambetta, "Can We Trust Trust?" in Gambetta, ed., Trust, 230; and Cook, Hardin, and Levi, Cooperation without Trust? 169, 186. 
by Khrushchev's institutional experiments and that some sort of alternative would be required if the regime were to lower the high transaction costs of the Soviet system. ${ }^{114}$ That alternative involved forging informal understandings and ad hoc local solutions grounded in ongoing personal relationships. The evidence for this is necessarily indirect given that few political leaders, no less Soviet ones, would ever speak openly in these terms. Nonetheless, in their speeches Soviet leaders did talk, albeit obliquely, of "trust in cadres" in ways that would be recognizable to comparative theorists of trust. It was in this vein that Soviet rulers, especially regional ones, spoke of the "mutual trust" and "deep trust" that had sprung up among officials, that they associated the "close ties" and "active help" between officials in Moscow and regional party leaders with "supreme trust," and that they praised the "trusting attitude" that had implanted itself in the "activity of all levels of our party." 115 Arguably, it was because it pointed to a shift from formal institutional devices to ongoing personal relations as a means of governance that the term trust, now often decoupled from the slogan "trust in cadres," became so prolific by the mid-1970s. ${ }^{116}$ Further indirect evidence of the emergence of what we might view as trust relations in the regions comes from another source. Theoretical analysis suggests that trust relations are most likely to arise where there are some limited but stable institutional constraints on politicians and where power differentials are relatively modest. ${ }^{117}$ Of the ideal-types identified by Khlevniuk, the one that most closely fits this theoretical template is the one that, I have suggested, became most widespread under Brezhnev, the "norm-bound network."

Perhaps the firmest evidence of what "trust" meant in practice was the precedent set by Brezhnev himself in his relationship with the regional first secretaries. The general secretary took an active interest in their selection and insisted on interviewing most of them personally prior to their appointment. ${ }^{118}$ To maintain good relations, Brezhnev would spend up to two hours a day speaking to regional leaders on the phone and, as a growing number became members of the Central Committee, he came to have face-to-face meetings with them in Moscow as well. ${ }^{119} \mathrm{~A}$ subgroup of these

114. Although relatively little has been written on trust and transaction costs in the Soviet context, the argument that trust lowers transaction costs is now standard across much of the comparative literature. A famous forerunner of this position can be found in Kenneth Joseph Arrow, The Limits of Organization (New York, 1974), 23. For a more recent survey, see Cook, Hardin, and Levi, Cooperation without Trust? 52-53, 76. For an analogous argument, albeit one couched in very different terms, made with regard to the Soviet political system in the Brezhnev period, see Willerton, Patronage and Politics, 230.

115. XXIV S"ezd, 1:194, 511; XXV S"ezd Kommunisticheskoi partii Sovetskogo Soiuza, 25 fevralia-5 marta 1976 goda. Stenograficheskii otchet (Moscow, 1976), 1:145, 177, 421.

116. For various examples of regional leaders greeting the discourse of "trust" with avid enthusiasm, see $X X I V S^{\prime \prime} e z d, 1: 142,194,203,244,355,441,511,575 ; X X V S^{\prime \prime} e z d, 1: 145$, $177,228,336,387,420-21,434$.

117. For an early version of this position, see Gambetta, "Can We Trust Trust?" 21819. A more recent and elaborate treatment can be found in Cook, Hardin, and Levi, Cooperation without Trust? 42, 53-55.

118. Gorbachev, Zhizn' i reformy, 1:123.

119. From 1966 to 1976 the number of obkom first secretaries in the RSFSR who were full members of the Central Committee rose from 36 to 60, all of whom were now 
regional leaders enjoyed special access to the leader. When, as a newly appointed regional first secretary, the young Mikhail Gorbachev visited Moscow in July 1970 to attend a session of the Supreme Soviet, he was introduced by the leader of the neighboring Krasnodar krai, Grigorii Zolotukhin, to a group of obkom leaders who, in Gorbachev's words, "enjoyed the special trust of the general secretary [pol' sovavshaiasia obsobym doveriem genseka]." "The first question they put to me straight [bukval' no v lob]," he recounted: "'How is your relationship with Leonid Il' ich coming along?' For all those present this was, it seemed, the key criterion of trust [glavnym kriteriem doveriia]." ${ }^{120}$ Much the same point was made by Brezhnev's son-in-law, Iurii Churbanov who, referring to the same group of regional leaders, recalled: "Leonid Il'ich knew these people well and he trusted them completely [doverial im polnost'iu]. To them, his doors were never closed."121

Brezhnev's mode of leadership permeated down to all regional leaders, even those outside this charmed circle. "The style [of work] now firmly established in the Central Committee and the Politburo," declared the first secretary of Kemerovo obkom at the Twenty-fourth Party Congress in 1971, "has created an environment in the regions that encourages . . . the further unfolding of creative initiative and enterprise ... among the cadres." ${ }^{22}$ From their point of view, regional first secretaries saw Brezhnev's proclamations of "trust in cadres" as a prompt to build ongoing relationships on a similar basis with their own regional officials. Akin to the nonmarket reciprocal relations described elsewhere for the Brezhnev period, these relationships were nonetheless not private but firmly embedded in state structures. ${ }^{123}$ There were dangers in relying so heavily on "trust" as a means of ensuring cooperation in such a large and complex system, however. In some cases, as in Krasnodar, the effect of practices that emerged under cover of the trust campaign was quite corrosive of the fabric of the state. It is with regard to the flourishing of this type of behavior that we can say that, under Brezhnev, the regime suffered from "too much trust." 124

guaranteed regular trips to the Kremlin in order to attend Central Committee plenums. Rigby, "Soviet Regional Leadership," 22.

120. Gorbachev, Zhizn' i reformy, 1:140-41. Emphasis added. Equally, Gorbachev recalled: "Every [first secretary] knew full well that he would be stripped of his office and all his power the moment . . . he lost the trust of the general secretary [ budet poteriano doverie genseka]." Ibid., 1:123.

121. Cited in Sokolov, Leonid Brezhnev, 206.

122. XXIV $S^{\prime \prime} e z d, 1: 567$.

123. Cf. James R. Millar, "The Little Deal: Brezhnev's Contribution to Acquisitive Socialism," Slavic Review 44, no. 4 (Winter 1985): 697, 701-2.

124. Most studies of trust do not see it as a fungible or measurable entity, or as a resource that could be "depleted through use" so that technically one cannot envisage "too much" of it. See Gambetta, "Can We Trust "Trust," 234. By "too much trust" I mean that the regime became overly reliant on ongoing personal relationships as a means of rule as opposed to the properly functioning institutions and external guarantees of trustworthiness that in other societies play the dominant role in ensuring large-scale cooperation. See Hardin, Trust and Trustworthiness, 47, 60-62; Cook, Hardin, and Levi, Cooperation without Trust? 1, 133-34, 141, 147, 185-86. 